\title{
TERRESTRIAL VEGETATION AND ENVIRONMENTS ON HEARD ISLAND
}

\author{
by D.M. Bergstrom and P.M. Selkirk
}

(with three tables, one text-figure, one plate and an appendix)

Bergstrom, D.M. \& Selkirk, P.M., 2000 (30:vi): Terrestrial vegetation and environments on Heard Island. In Banks, M.R. \& Brown, M.J. (Eds): HEARD ISLAND PAPERS. Pap. Proc. R. Soc. Tasm. 133(2): 33-46. https://doi.org/10.26749/rstpp.133.2.33 ISSN 0080-4703. Department ofBotany, The University of Queensland, Brisbane, Queensland, Australia 4072 (DMB); and Department of Biological Sciences, Macquarie University, Sydney, New South Wales, Australia 2019 (PMS)

Significantly ice-covered and with a very small flora (11 vascular species and about 60 bryophyte taxa), Heard Island is still emerging from the effects of the last glacial maximum. This study presents the results of a general vegetation survey. A baseline framework of environmental conditions that affect vegetation on the island is described and a classification (TWINSPAN) analysis based on presence/ absence data of both vascular plant species and bryophyte taxa is provided. Distinct suites of taxa were identified on the island, some containing bryophytes only. Fifteen ecological groups were delineated. A discussion of ecological amplitude of important bryophyte and vascular plant taxa on Heard Island is included.

Key Words: Subantarctic, tundra, vegetation, bryophytes, cushion plants, Heard Island.

\section{INTRODUCTION}

Subantarctic Heard Island ( $\left.53^{\circ} 06^{\prime} \mathrm{S}, 73^{\circ} 32^{\prime} \mathrm{E}\right)$ is approximately $4850 \mathrm{~km}$ southeast of southern Africa, $4350 \mathrm{~km}$ southwest of Western Australia and $1650 \mathrm{~km}$ north of the Antarctic continent. It is an emergent portion of a midoceanic ridge with a mixed geology of pelagic limestones and volcanics (Clarke et al. 1983), with a large active volcano (Big Ben - $2750 \mathrm{~m}$ ) dominating the landscape. The island is $44 \mathrm{~km}$ long on a WNW-ESE axis.

Heard Island has a history of glaciation from the Miocene (Quilty et al. 1983), with many glaciation events associated with cooling episodes in the Pleistocene. Severely glaciated today, it is essentially still emerging from the last glacial maximum approximately 18000 years ago (Climap 1976). Allison \& Keage (1986) estimated that, in 1980, approximately $80 \%$ of Heard Island was ice-covered, with glaciers descending from $2400 \mathrm{~m}$ to sea-level. Ice-free areas lie, in general, along the coastline and rarely extend above $400 \mathrm{~m}$ a.s.l. As glaciers isolate these ice-free areas, each can be considered analogous to an individual island and Heard Island analogous to an archipelago (Bergstrom \& Selkirk 1997). Glacial retreat is occurring rapidly with current climate warming (Scott 1990), with some ice-free areas coalescing.

Heard Island has a remarkably equable temperature regime both diurnally and annually, moderated largely by the surrounding ocean. Weather station data collected between 1948 and 1958 recorded a mean annual temperature of $1.2^{\circ} \mathrm{C}$, with a seasonal range of $4.5^{\circ} \mathrm{C}$. Snow or rain falls on most days of the year, and the island is severely ravaged by wind storms, mostly from the northwest to southwest quadrants (Allison \& Keage 1986).

About $5 \%$ or $20 \mathrm{~km}^{2}$ of the total surface area of Heard Island is covered by substantial vegetation. Low-growing, herbaceous flowering plants and bryophytes are the major plant components. Only 11 flowering plant species and 58 bryophyte species have been recorded from the island (Scott 1989, Bergstrom \& Seppelt 1988, Bergstrom \& Selkirk 1997). A different and perhaps more extensive vegetation, described as a low scrubby fernbush, existed on the island during the Tertiary and included a variety of ferns and a podocarp (Quilty et al. 1983).

There have been few studies of terrestrial plant ecology on Heard Island. Jenkin (1980) briefly described five vascular plant communities on Heard Island. In a preliminary study, Hughes (1987) expanded this to six. These communities are visually recognisable though subjective, and are based on physiognomic, microtopographic and some floristic features. Scott defined six mappable vegetation units based on Hughes' (1987) scheme and provided more detailed descriptions of the vascular plant communities. A summary of the six vascular plant communities follows. (1) "Poa cookii maritime grassland" is characteristic of nutrient-enriched, animal influenced environments (Hughes 1987, Scott 1988). This community is dominated by the small tussock grass Poa cookii (Hughes 1987), with the nitrophiles Callitriche antarctica and Montia fontana also common.

(2) "Pool complex" occurs in areas where drainage is impeded. Callitriche antarctica is the indicator species (Hughes 1987, Whinam 1989). Whinam (1989) delineated eight ecological groups within this community depending on extent of cover by Azorella selago and a mixture of other species. Areas which can be categorised as pool complex vegetation most often occur inland of a narrow fringe of maritime grassland on coastal flats. These areas are subjected to seasonal disturbance by wallowing and moulting elephant seals and fur seals.

(3) "Meadow community" categoryencompasses vegetation dominated by either of two grass species: Poa cookii or, at some sites at the eastern end of the island, Deschampsia antarctica. Such communities are reported from environments where the water table is close to the surface. Usually bryophytes are common, as are the vascular plants Montia fontana, Acaena magellanica and Callitriche antarctica (Scott 1988).

(4) "Herbfield" is dominated by either of two herb species: Pringlea antiscorbutica or Acaena magellanica(Hughes 1987 , Scott 1988). Acaena magellanica has only been recorded from the eastern end of the island (Scott 1988). Herbfield has been reported from a variety of situations such as sheltered moraine slopes and gullies. Stands can be mono- 
specific or mixed, with Azorella selago and Poa cookii being a subsidiary species. Pringlea antiscorbutica can colonise scree slopes, landslip surfaces and recently deposited moraines. It is also common along gravelly stream margins (Hughes 1987, Scott 1988).

(5) "Cushion carpet vegetation" is dominated by Azorella selago. In this vegeration category, individual cushions of A. selago coalesce into continuous carpets. Hughes (1987) described cushion carpet communities occurring in locations of moderate to high wind exposure. This type of vegetation is the most widespread on Heard Island, occurring throughout the altitudinal range of vegetation. Scott (1988) recognised five subcategories: "dense cushion carpet", "patchy cushion carpet", "AzorellalPoa cookii network vegetation", "Azorella mossfields" and vegetated cliff edges and ledges. "Dense cushion carpet" is almost completely dominated by A. selagowith sporadic occurrence of Poa cookii, P. kerguelensis, Colobanthus kerguelensis and bryophytes. "Dense cushion carpet" grades to "patchy cushion carpet". "AzorellalPoa cookii network vegetation" occurs in dense cushion carpet on a variety of slopes, and from a distance presents a network appearance. "Azorella mossfield" vegetation consists of dense carpets of bryophytes between $A$. selago cushions.

(6) "Feldmark communities" are characterised by less than $50 \%$ vegetation cover. Hughes (1987) described feldmark as having high relative vascular plant diversity but low species abundance, with predominant plants being Azorella selago, Poa kerguelensis, Colobanthus kerguelensis, Pringlea antiscorbutica, bryophytes and lichens. Scott (1988) recorded feldmark on well-drained areas of high altitude/high wind exposure, areas of recent glacial retreat, flat valleys likely to be subject to cold air drainage, and geologically recent lava flows.

This paper documents a general vegetation survey conducted on Heard Island during the 1986/87 ANARE expedition. First, a framework of environmental conditions that affect vegetation on the island is set. Second, the results of a classification (TWINSPAN) analysis are presented. In particular, this analysis emphasises the diversity of bryophyte taxa within common vegetation types and landscape units on the island. The previous plant community studies described above focused on the vascular plant component, generally amalgamating all bryophytes into a single taxon "bryophytes" (Hughes 1987, Whinam 1989) or a small number of collective groups (Scott 1990). Total bryophyte cover is a useful measure, but information on plant community complexity and species richness is not gathered. Considering that on Heard Island there are five times as many bryophyte taxa (53) as vascular taxa (11) (Bergstrom \& Seppelt 1988, Bergstrom \& Selkirk 1997), the loss of information consequently is large. Finally a discussion of ecological amplitude of important bryophyte and vascular plant taxa on Heard Island is presented.

\section{ENVIRONMENTAL COMPONENTS THAT AFFECT HEARD ISLAND PLANTS AND PLANT COMMUNITIES}

In this section, major environmental components that are significant to plants and plant communities are identified and their variation on the island described. Most have yet to be described quantitatively. They are listed here with a view to future studies on Heard Island.

\section{Animal-derived Nutrients}

In identifying patterns of variation in the climates, soils and vegetation on some Subantarctic islands, Smith \& French (1988) recognised changes in soil chemistry, caused by manuring by seals and seabirds, as a major component affecting vegetation. Heard Island was not considered in their study, but animal-derived nutrients are of major importance there. A nutrient gradient is apparent, diminishing away from coastal seal and bird-breeding, resting and hauling-out areas. Areas affected by direct manuring by seals, penguins, cormorants and giant petrels are generally devoid of vegetation, reflecting toxic nutrient levels and physical damage to plants. In some areas, such as the periphery of a Gentoo penguin rookery inland of Spit Bay hut, scorching of plants by guano was evident.

Volatilisation of ammonia from penguin rookeries and subsequent deposition on vegetation downwind has been reported both on Macquarie Island (Jenkin 1975, Erskine et al. 1998) and on Marion Island (Lindebloom in Gremmen 1982). Areas adjacent to penguin and giant petrel rookeries support lush growth of Poa cookii, blue-green in colour, indicative of high nitrogen levels.

Direct small-scale nutrient input in the vegetation associated with burrowing petrel nests is likely to be of significance. Scott (1988) reported petrel nests in most vegetation types on Heard Island.

\section{Dissolved Nutrients from Parent Rock}

The influence of dissolved nutrients from parent rock on plants has yet to be determined. Most lavas on Heard Island are alkali basalts (Australian Antarctic Division 1995), as are the lavas on Marion (Verwoerd 1971). However, in an extensive plant ecological study on Marion Island, Gremmen (1982) recorded most sites having acidic pH levels. Unusually high levels of titanium and related elements have been reported from lavas on Mt Dixon, Laurens Peninsula (Australian Antarctic Division 1995).

Limestone deposits occur at various localities on the island (Quilty et al. 1983). There appears to be no distinct suite of limestone plant species. Quadrats surveyed on limestone moraines at the base of Anzac Peak, Laurens Peninsula, had similar bryophyte species composition to lava sites in the same area (see TWINSPAN Group 2, appendix). In Eastern Australia, basalt and limestone areas in the Blue Mountains have similar bryofloral components (A. J. Downing, pers. comm.).

\section{Sea-salts}

Deposition of sea-salts on Subantarctic islands can occur in a number of ways. In heavy storms, waves can splash directly onto coastal margins such as lava cliffs. Airborne sea-spray can be incorporated into winds blowing over land- and airborne sea-salt particles can be "scavenged" from the atmosphere and deposited on land in precipitation (Mallis 1988). On other Subantarctic islands, deposition gradients appear to be related to the direction of the prevailing wind and settling mist (Mallis 1988, Smith 1987).

Similar patterns are evident on Heard Island. Halophytes, such as the moss Muelleriella crassifolia subsp. acuta, occur some distance inland on the south and southwestern sides 
of the Laurens Peninsula and in the Long Beach region (regions that receive the brunt of the prevailing winds), but can only be found on beach-side rocks in the more sheltered Spit Bay region.

\section{Water Availability}

Many factors contribute to the variation in availability of water on the island. Although snow or rain falls on most days, local precipitation varies. Expeditions have reported that the eastern ice-free areas, such as the Spit Bay region, may have a generally less severe climate than on the northwestern and southern sides of the island, with reduced cloud cover and precipitation. The controlling factor appears to be forced uplift of westerly or southwesterly moist air bodies over Big Ben (Ledingham 1987).

Extensive snow cover in winter provides spring meltwater, varying with local topography. Topographic depressions can allow accumulation of snow or ice which, on melting, provides free water for local vegetation. Scott (1988) reported meadow vascular plant communities in areas below late-lying snow banks.

Another major input of water is meltwater from glaciers (which feed creeks and outwash lakes) and from ice-cored moraines (permafrost) such as in areas of Dovers Moraine, in the Spit Bay region, where ice lenses extend into peats. In summer, in some areas, constant subsurface lateral water flow is available to deep-rooted plants such as Azorella selago.

Loss of moisture from terrestrial environments on the island is mainly influenced by evaporation rates and drainage rates. Most areas are subjected to strong, drying winds at some time. Very exposed areas could be described as wind deserts, with any precipitation being blown away or rapidly evaporated. In such areas, wind-driven mist may be the only source of moisture, making the environments suitable for ectohydric bryophytes but not endohydric vascular plants.

Drainage rates vary considerably on Heard Island. A large proportion of ice-free moraine, clinker lava and aeolian areas are free draining, but drainage rates are reduced in some areas. Solid beds or smooth lava (pahoehoe lava), such as near the ANARE base, can present a non-porous bedrock surface. Weathering in some areas, such as on the moraines directly behind Manning Lagoon (Long Beach region) or on the lavas near the alluvial flats, south of Anzac Peak (Laurens Peninsula), has yielded clay particles which increase the water-holding capacity of the substrate, as does accumulation of peat. There are a few areas of saturated peats on Heard Island, such as near the creekline draining into Sydney Cove on the Laurens Peninsula, and moraines directly behind Manning Lagoon in the Long Beach region.

In areas of impeded drainage, small pools or tarns occur, fed by local catchment areas. Pools at elevations above coastal plains are generally oriented parallel to lava ridges (Whinam 1989), suggesting topographic control of pool formation. On coastal plains and beach terraces, animal activity, in particular seal wallowing, contributes to reduced drainage (Whinam 1989).

\section{Substrate Depth}

Substrate depth and, hence, volume available for vascular plant root systems varies considerably in ice-free areas. Large areas of solid lava are either bare or thinly covered with cryptogamically derived peat. In rocky areas, such as clinker lava flows and scoria cones (pl. 1A, see p. 41), wind-blown sediment accumulates between rocks. Deep $(>0.5 \mathrm{~m})$ unconsolidated substrates can generally be found on moraines, talus slopes, aeolian deposits and beach terraces. Peat deposits, derived mainly from Azorella selago, up to $2 \mathrm{~m}$ deep were measured on moraines in the Spit Bay region.

\section{Particle Abrasion}

Abrasion of plants by windblown particles, including sand, ash, snow and ice, is a major environmental disturbance on Heard Island. Ventifacts are evident in many exposed areas, such as along the Spit.

\section{Surface Movement}

Surface movement in ice-free areas on Heard Island can cause considerable reworking of the land surface and will affect dynamics of colonisation by plants here as on Macquarie Island (Bergstrom \& Selkirk 1999).

Downslope movement occurs on unstable moraine slopes, talus slopes and scoria cone slopes. Frost-heaving, frostraking and nubbin formation were observed between cushions of Azorella selago on moraine sediments. Sorted stripes occur on scoria and ash/sand sediments at the northern base of $\mathrm{Mt}$ Dixon. On the limestone moraines at the southern base of Anzac Peak, there were stone polygons up to $8 \mathrm{~m}$ in diameter.

Fluvioglacial activity is modifying terrestrial plant habitats on Heard Island. Entrapment of sediment in coastal glacial lagoons, redeposition and beach formation is generating new surfaces that can be colonised by terrestrial plants.

Although moraine surface material provides some insulation, ice-core melting occurs in midsummer. Slumping of surface material and burial of bryophyte vegetation was observed in 1987 in the higher areas (above $60 \mathrm{~m}$ a.s.l.) of Dovers Moraine, to the east of King Creek.

\section{Biotic Interactions}

Vertebrate animals disturb ground by trampling as well as adding nutrients. Scott (1988) described habitats used by seals and seabirds. Whinam (1989) described intensive use of coastal vegetation by penguins and seals and reported destruction of Poa cookii tussocks by giant petrels.

On Marion Island, herbivory is insignificant. Most energy flow and nutrient cycling occurs through the detritus level. The main mediators for nutrient mineralisation are soil macro-invertebrates (Smith \& Steenkamp 1990). Such macro-invertebrates are also found on Heard Island and are likely to play a similar role. 


\section{General Climate Characteristics}

Temperature gradients on the island appear to affect plant physiology. Phenological stages in vascular plants appear to be influenced by the milder climatic condition of the eastern areas compared with the northwestern and southern areas. In early December 1986 at Atlas Cove, Pringlea antiscorbutica and Azorella selago plants had flowerbuds within the rosette and cushion respectively. Poa cookii was in flower, but stamens were not mature. Plants growing in the Spit Bay region at the same time were advanced by at least two weeks in development. Azorella selago flowers were open, Pringlea antiscorbutica flowerheads were well elevated above the rosette and Poa cookiistamens had emerged with ripe pollen.

Table 1 lists major influences on present Heard Island vegetation and categorises them as "stress" or "disturbance" in the sense of Grime (1979). It is clear, however, that stress and disturbance are interlinked, since disturbance creates stresses for plants, and at times the categories are difficult to separate clearly.

Environmental components such as nutrients can have diametrically opposite effects, depending on their availability. For example, lack of nutrients can inhibit plant growth, excess nutrients can be toxic. A subjective scale is presented in table 1.

\section{VEGETATION SURVEY AND CLASSIFICATION ANALYSIS}

\section{Methods}

The basis of this study is a vegetation survey conducted on Heard Island during the 1986/87 Australian National Antarctic Research Expedition (ANARE). A stratified random sampling approach was adopted in selecting field sites. A total of $475,1 \times 1 \mathrm{~m}$ quadrats were surveyed during the eight-week field period. Sites were chosen to cover as many visibly distinct vegetation types as possible. Most quadrats (400) were either part of ten random quadrats in a series of $10 \times 10 \mathrm{~m}$ areas, sampling recognisable landscape units/vegetation types, or were components of transects over distinct landscape features (such as creeks). The remaining samples were isolated quadrats.

In each quadrat the following habitat characteristics were noted:

- location;

- geomorphological description (moraine, clinker lava, lava flow or sand) and general notes on topography.

- altitude;

- general slope of the quadrat (although in clinker lava sites such values are meaningless, due to the irregularity of these sites);.

- aspect;

- unconsolidated substrate depth up to $100 \mathrm{~cm}$ depth measured using a $1 \mathrm{~cm}$ diameter metal probe;

- availability of water, rated on a subjective five-point exponential scale ranging from 1 (very dry) to 5 (surface free water);

- exposure to wind, rated on a subjective five-point scale ranging from 1 (very protected) to 5 (very exposed);

- availability of light, rated on a subjective five-point scale ranging from 1 (exposed to full light conditions) to 5 (deep shade).
In each quadrat, cover values using the Braun-Blanquet (1932) scale were recorded for all vascular plants, bryophytes (as a collective unit), bare ground and rock. Braun-Blanquet cover values (+ to 5) were transposed to a scale, 1 to 6 , to facilitate numerical analysis. Notes on individual cover values for major bryophyte taxa were also taken. Small samples of all bryophyte taxa were collected from each quadrat for identification in Australia.

Working in such a remote locality as Heard Island presents inherent logistic difficulties. Available field time was short. Transport between ice-free areas was by helicopter, commonly grounded by unfavourable weather. Access within major ice-free areas was generally by foot over difficult terrain. It was necessary to conduct fieldwork opportunistically: a consequence of this is uneven sampling. We were fortunate to have the opportunity to conduct fieldwork in three major ice-free areas on the island: the northwest areas encompassing the Laurens Peninsula, the Azorella Peninsula and Mt Drygalski; the eastern Spit Bay area; and the southern Long Beach area. Time spent in each of these areas was, however, uneven, and this is reflected in the number of quadrats collected from each (table 2).

Data was classified using TWINSPAN (Hill 1979), a polythetic divisive method of ordination and classification. The analysis constructs an ordered two-way table of taxa and sites by identification of differential (discriminating) species. Sites are classified first and taxa second, using the site classification as a basis. Levels of division are determined by the coherence of the ecological groups obtained. An "indicator" ordination is performed, in which highly preferential taxa or "indicator taxa" within ecological groupings are identified and ranked.

A preliminary analysis of the vegetation survey data set was performed using the Braun-Blanquet cover values for all the vascular species recorded and total bryophyte cover. Assignment of cover values for individual bryophyte taxa was not possible as field identification of such plants is not reliable; laboratory study has been necessary for accurate identification. The dendrogram generated for this analysis was compared with another analysis in which only presencel absence data were used, but included information on individual bryophyte taxa. A comparison showed that there was no significant change in the overall position of the vascular plant taxa in the dendrogram with reduction from cover values to presence/absence data. A TWINSPAN analysis of the data set using presence/ absence data only is presented here.

\section{Results and Discussion}

Figure 1 presents the dendrogram of the taxon classification. Fifteen taxon clusters (a-o) were identified, indicating distinct suites of plant species on Heard Island. In particular, there are distinct suites of bryophyte taxa that commonly occur together, with nine of the 15 clusters containing bryophytes only. The primary split in the data accounted for $68 \%$ of the variance in the data.

As well as 15 taxon clusters, 15 ecological groups (Groups 1-15) were delineated in the TWINSPAN analysis of the 475 quadrats. These groups contain between 13 and 67 quadrats. The frequency of occurrence of taxa in each of these 15 groups is shown in table 3 . The TWINSPAN taxon clusters of figure 1 are maintained in this table. 
TABLE 1

Summary of some of the major influences that affect plants on Heard Island

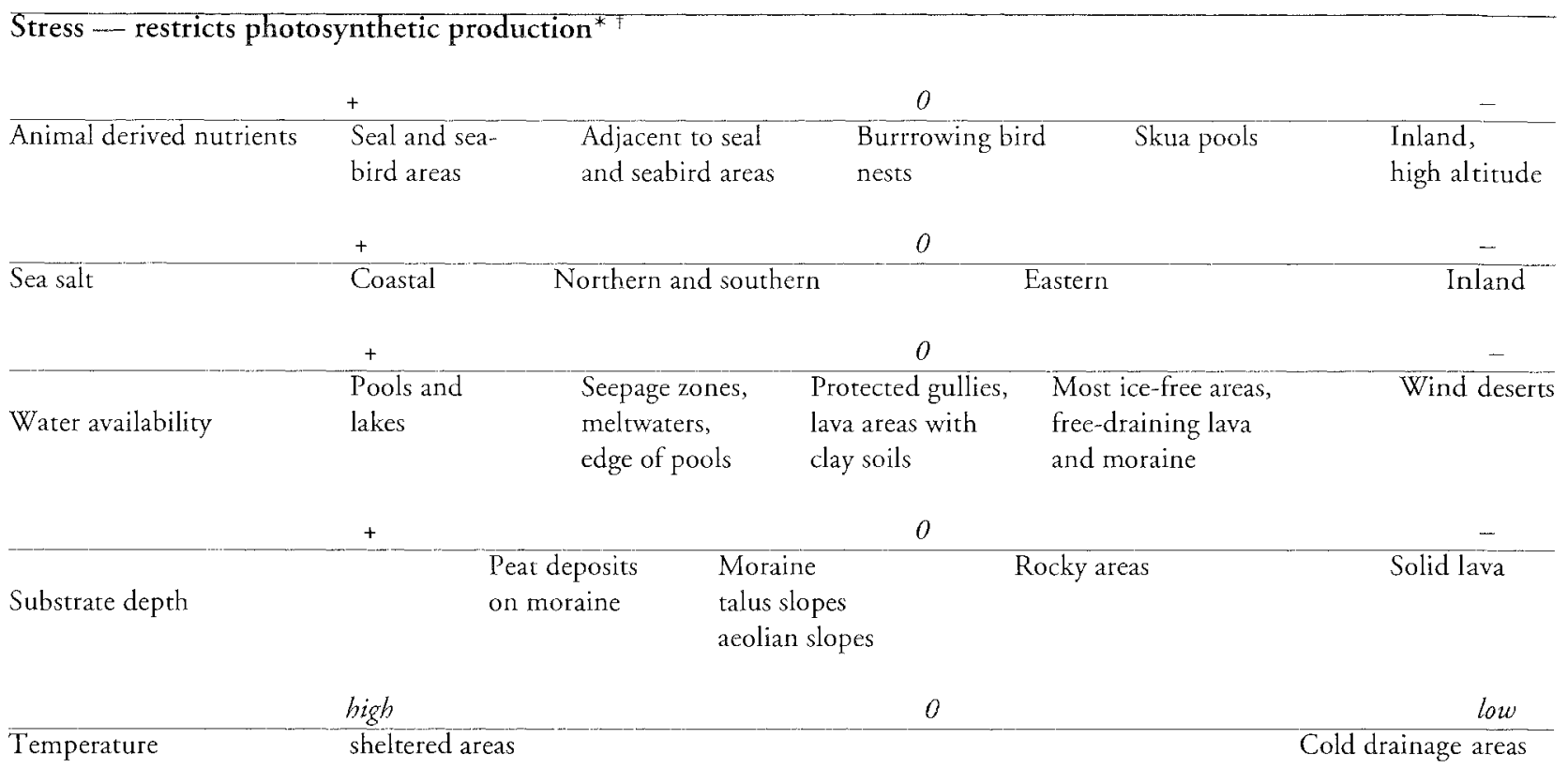

\section{Disturbance - partial or total destruction of biomass* *}

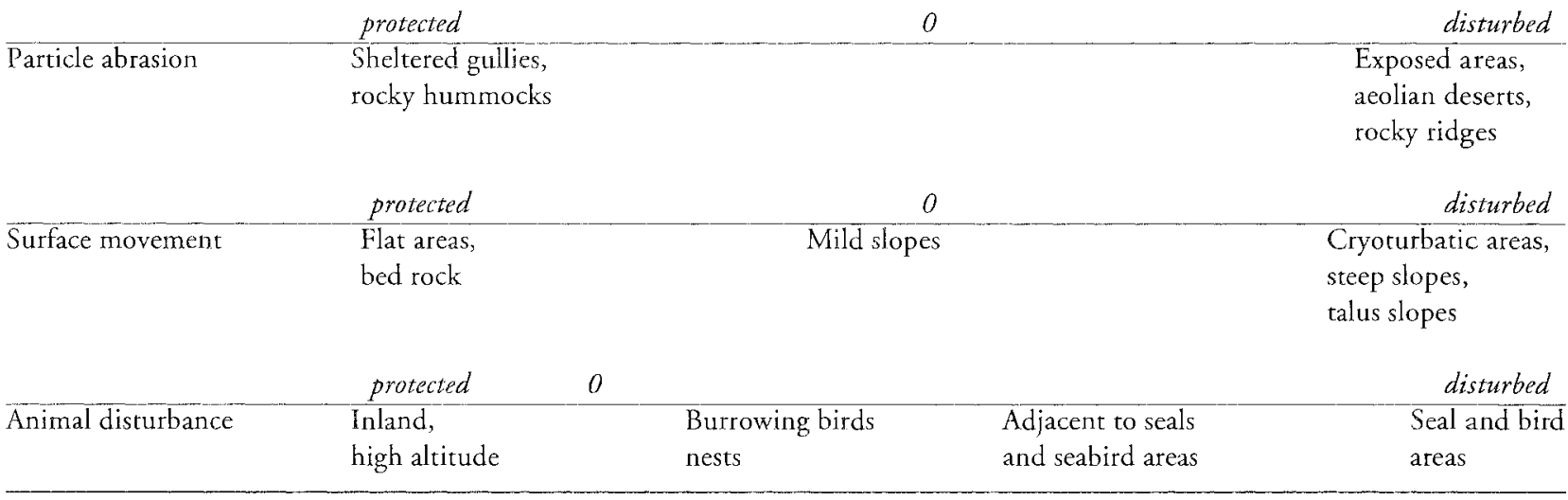

* $0=$ midline (parameter perhaps being terned abundant) ${ }^{\dagger}+$ and $-=$ extremities.

subjective scale ranging from protecred to disturbed.

TABLE 2

Number of quadrats suryeyed in each majot ice-free area of Heard Island

\begin{tabular}{lr}
\hline Area & Quadrat no. \\
\hline Laurens Peninsula & 119 \\
Azorelia Peninsula & 40 \\
Mt Drygalski & 10 \\
Spit Bay & 250 \\
Long Beach & 45 \\
Other areas & 11 \\
\hline
\end{tabular}

The cushion plant, Azorella selago, stands isolated in figure 1. This is of interest and relates to two aspects of the ecology and distribution of $A$. selago on the island. Firstly, A. selago is the largest and most dominant plant on Heard Island today, with Scott's (1988) vegetation categories of patchy cushion carpet and dense cushion carpet dominated by $A$. selago being most common. Secondly, A. selago exhibits wide ecological amplitude.

There are a number of salient features to table 3 . The ubiquitous nature of $A$. selago is highlighted, occurring in all 15 ecological groups. Azorella selago was recorded from $80 \%(379 / 475)$ of all quadrats in this study. Six other species/species complexes can be classified as having wide ecological amplitude: the bryophytes Dicranoweisia spp., Polytrichastrum alpinum, Fossombronia australis, Bartramia patens and Ceratodon purpureus and the vascular species Poa kerguelensis and Colobanthus kerguelensis. Interestingly Dicranoweisia ssp. and Ceratodon purpureus were also recorded as having wide distributions on the island (table 3). 
TABLE 3

Frequency of occurrence of taxa in each of the 15 TWINSPAN groups ${ }^{*}$

\begin{tabular}{|c|c|c|c|c|c|c|c|c|c|c|c|c|c|c|c|c|}
\hline \multirow[b]{2}{*}{ Cluster } & & \multicolumn{15}{|c|}{ Twinspan Groups } \\
\hline & & 1 & 2 & 3 & 4 & 5 & 6 & 7 & 8 & 9 & 10 & 11 & 12 & 13 & 14 & 15 \\
\hline a & Dicranella sp. & 12 & 22 & 28 & 10 & & 3 & & & 9 & & 22 & & & & \\
\hline $\mathbf{a}$ & Sainionia uncinata & 56 & 31 & 68 & 50 & 7 & & & & 18 & 18 & 61 & 54 & & & \\
\hline a & Cryptochila grandiflora & & 2 & 5 & & & & & & & & & 8 & & & \\
\hline b & Schistidium falcatum & & 4 & 5 & 2 & & & & 3 & & & & & 3 & & \\
\hline $\mathbf{b}$ & Cephaloziella varians & & 17 & 40 & 44 & 7 & & & & & & & & 7 & & \\
\hline b & Lophocoleoideae sp. & & & 7 & 8 & 60 & & & & & & & & 7 & & \\
\hline b & Muelleriella crassifolia & & 2 & 3 & 2 & 7 & & & & & & & & 22 & & \\
\hline $\mathbf{b}$ & Pedinophyllopsis abdita & 6 & 83 & 60 & 73 & 80 & & & & & & & 8 & & & \\
\hline b & Herzogobryum vermiculare & 6 & 9 & 5 & 6 & & & & & & & & & & & \\
\hline b & Andreaea acuminata & & 26 & 3 & 4 & & 2 & & 3 & 2 & & & & & & \\
\hline b & Psilopilum australe & & 22 & 22 & 6 & & & & & & & & & & & \\
\hline b & Schistidium sp. & & 4 & & & & & & & & & & & & & \\
\hline $\mathbf{b}$ & Verrucidens spp. & 18 & 54 & 5 & 2 & & 3 & & & & & & & & & \\
\hline b & Dicranoloma billardierii & 12 & 17 & 5 & 2 & & & & & & & & & & & \\
\hline b & Pachyglossa fissa & 6 & 66 & 12 & 21 & & & & & & & & & & & \\
\hline b & Blepharidophyllum densifolium & 6 & 84 & 12 & 6 & 14 & & & & & & & & & & \\
\hline c & Racomitrium crispulum & 62 & 46 & 33 & 85 & 87 & 5 & 22 & & & 6 & & & & & \\
\hline c & Racomitrium lanuginosum & & 4 & & 6 & 7 & & & & & & & & & & \\
\hline c & Ditrichum immersum & 31 & 61 & 43 & 96 & 93 & 3 & 11 & & & & & & & & \\
\hline c & Herzogobryum atrocapillum & 18 & 26 & 5 & 19 & 73 & & & & & & & & & & \\
\hline$d$ & Andreaea mutabilis & 100 & 20 & 35 & & 7 & & & & 7 & & & & & & \\
\hline d & Grimmia sp. & 25 & & 3 & & & & & & & & & & & & \\
\hline d & Schistidium apocarpum & 75 & 9 & 8 & 4 & & 3 & & & & & & & & & \\
\hline d & Blindia robusta & 62 & 61 & 12 & & & 3 & & & & 6 & & & & & \\
\hline d & Ditrichum subaustrale & & 6 & 12 & 8 & 7 & 3 & & & 2 & & & & & & \\
\hline d & Hennediella heimii & 12 & & 3 & & 7 & & & 3 & & & & & & & \\
\hline$d$ & Tortula geheebiaeopsis & & 2 & 3 & & & & & 3 & & & & & & & \\
\hline$d$ & Cephaloziella exiliflora & 6 & 24 & 10 & 15 & & 3 & & 12 & 14 & & 4 & & & & \\
\hline e & Poa kerguelensis & 1 & 19 & 5 & 54 & 73 & 94 & 89 & 90 & 5 & & & & 7 & & \\
\hline e & Polytrichum piliferum & & 4 & & & & 6 & 50 & 16 & 18 & & & & & & \\
\hline e & Grimmia immerso-leucophaea & 56 & 20 & 3 & 10 & & 43 & 72 & 10 & 5 & & & & & & \\
\hline e & Dicranoweisia spp. & 31 & 85 & 70 & 94 & 13 & 87 & 83 & 83 & 63 & 31 & 9 & & 7 & & \\
\hline f & Colobanthus kerguelensis & & 28 & 3 & 52 & 47 & 81 & 78 & 83 & 5 & 56 & 35 & 8 & 64 & & \\
\hline f & Polytrichastrum alpinum & 18 & 39 & 45 & 50 & 20 & 76 & 55 & 50 & 81 & 12 & 65 & 8 & & & \\
\hline f & Ditrichum conicum & & 54 & 30 & 8 & & 30 & 28 & 43 & 47 & & 30 & & & & \\
\hline $\mathrm{g}$ & Fossombronia australis & 6 & 54 & 50 & 38 & & 37 & & 33 & 54 & 62 & 70 & 85 & 17 & & \\
\hline g & Jungermannia coniflora & & 4 & 12 & & & 2 & & & 2 & & 26 & 8 & & & \\
\hline $\mathrm{g}$ & Trichostomum sp. & & 2 & 3 & 2 & & 2 & & & & 6 & & & & & \\
\hline h & Pohlia wablenbergii & 69 & 15 & 38 & 4 & & 7 & & 40 & 7 & & 26 & 15 & & & \\
\hline $\mathbf{h}$ & Bartramia patens & 56 & 56 & 70 & 65 & & 21 & 5 & 70 & 49 & 50 & 70 & 15 & 3 & & \\
\hline i & Azorella selago & 6 & 93 & 85 & 98 & 86 & 100 & 77 & 67 & 88 & 94 & 100 & 23 & 75 & 69 & 100 \\
\hline $\mathbf{j}$ & Ceratodon purpureus & & 7 & 28 & & 13 & 2 & 61 & 72 & 67 & 56 & 48 & 8 & 34 & & \\
\hline $\mathbf{j}$ & Bryum dichotomum & & & 3 & & & 2 & 17 & 6 & 5 & 19 & & 69 & & & \\
\hline $\mathbf{j}$ & Bryum pseudotriquetrum & & 17 & 40 & 10 & & 16 & & 63 & 56 & 56 & 74 & & & & \\
\hline $\mathbf{k}$ & Pringlea antiscorbutica & & 16 & 15 & 12 & 27 & 7 & & 20 & 2 & 6 & 26 & & 46 & & 9 \\
\hline 1 & Bryum sp. 1 & & & 5 & & & & & 3 & 2 & & 4 & & 3 & & \\
\hline 1 & Bryum sp. 2 & & & 18 & & & & & 3 & & & 4 & & 11 & & \\
\hline 1 & Poblia sp. & 12 & 36 & 3 & 6 & & 2 & 5 & 33 & 46 & 56 & 48 & 61 & 7 & & \\
\hline 1 & Marchantia berteroana & 31 & & & & & & & 13 & 16 & & 65 & & 7 & & \\
\hline $\mathbf{m}$ & Acaena magellanica & & & & & & & & & 30 & 31 & 74 & 54 & & 4 & 27 \\
\hline $\mathbf{m}$ & Deschampsia antarctica & & & & & & & & & 2 & 6 & 48 & 69 & & & \\
\hline $\mathbf{n}$ & Philonotis angustifolia & & & & & & & & & 2 & 6 & 17 & 38 & & & \\
\hline $\mathbf{n}$ & Brachythecium spp. & 6 & 4 & 8 & & & & & 3 & 2 & 12 & 17 & 54 & 3 & & \\
\hline o & Poa cookii & & 13 & 25 & 4 & & 3 & 5 & 10 & 7 & 93 & 78 & 64 & 78 & 96 & 9 \\
\hline o & Montia fontana & & 2 & & & & & & & & 50 & 9 & & 28 & 13 & \\
\hline o & Callitriche antarctica & & & 3 & & & & & & & 69 & 56 & 23 & 34 & 35 & \\
\hline & Number of quadrats/groups & 17 & 54 & 40 & 51 & 15 & 67 & 18 & 30 & 42 & 16 & 23 & 13 & 31 & 22 & 22 \\
\hline
\end{tabular}

* Expressed as a percentage of the total number of quadrats/groups. TWINSPAN Taxon Clusters (fig. 1) indicated by letters $\mathbf{a}-\mathbf{o}$. 
a

Dicranella sp.

Sainionia uncinata Cryptochila grandiflora

Schistidium falcatum Cephaloziella varians Lophocoleoideae sp. Muelleriella crassifolia

b Pedinophyllopsis abdita Herzogobryum vermiculare Andreaea acuminata Psilopilum australe Schistidium sp. Verrucidens spp. Dicranoloma billardierii Pachyglossa fissa Blepharidophyllum densifolium

Racomitrium crispulum

c Racomitrium lanuginosum Ditrichum immersum Herzogobryum atrocapillum

Andreaea mutabilis Grimmia sp.

Schistidium apocarpum Blindia robusta Ditrichum subaustrale Hennediella heimi Tortula geheebiaeopsis Cephaloziella exiliflora

*Poa kerguelensis Polytrichum piliferum Grimmia immerso-leucophaea Dicranoweisia spp.

*Colobanthus kerguelensis Polytrichastrum alpinum Ditrichum conicum

Fossombronia australis

9 Jungermannia coniflora Trichostomum sp.

h Pohlia wahlenbergii Bartramia patens

i Azorella selago Ceratodon purpureus i Bryum dichotomum Bryum pseudotriquetrum

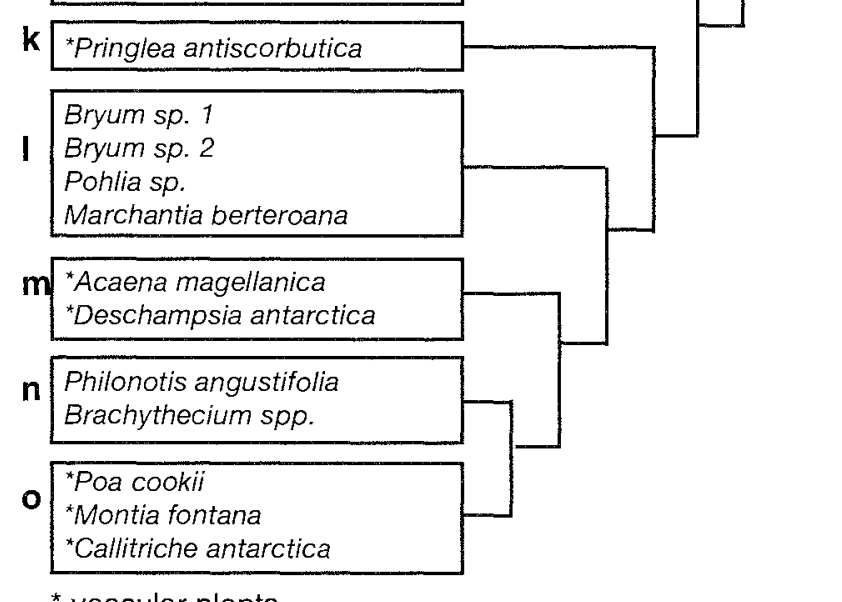

* vascular plants
Taxa in Cluster a generally occur between Groups 1-4 and 9-12. Clusters b, c and d have particularly strong frequencies of occurrence in Groups 1-5 (table 3). Clusters $\mathrm{e}-\mathrm{l}$ are generally widespread across the groups with a number of common taxa (taxa with high frequencies of occurrence). Clusters $\mathrm{m}, \mathrm{n}$ and $\boldsymbol{o}$, with the exception of $P$. cookii, are generally confined to Groups 10-15.

Bryophyte species richness is particularly high in Groups 1-4 and relatively low in Groups 7, 12 and 13. Bryophyte taxa are absent from Groups 14 and 15. Vascular species richness is less varied, highlighting Scott's (1990) observation that one of the features of the vegetation of Heard Island vegetation is the small number of vascular species occupying a large range of habitats. However, Group 1 contains only two vascular species, $P$. kerguelensis and $A$. selago.

Details of each of the 15 TWINSPAN Groups are included in the appendix.

\section{ECOLOGICAL NOTES ON IMPORTANT TAXA}

Following are descriptions of life form (Gimingham $\&$ Birse 1957), ecological amplitude and ecological strategies of abundant or significant terrestrial plant taxa on Heard Island.

\section{Bryophytes}

\section{Bartramia patens}

Life form: Single moss stems to loose moss carpets.

Ecological amplitude: Although not extensive in cover, Bartramia patens is a widespread species on Heard Island. It is particularly prevalent in micro-habitats that are moist and have low light levels, such as between rocks.

0.68 Notes: As on Heard Island, B. patens is usually found in sheltered or shaded habitats on Macquarie Island. Hebrard (1970) reported Bartramia as occurring preferentially on acidic environments on Îles Kerguelen and Îles Crozet.

\section{Dicranoweisia species complex}

Life form: Moss cushion and turf including aquatic, black, loose turf in creeks.

Ecological amplitude: Dicranoweisia species complex is the most abundant bryophyte taxon on Heard Island. It exhibits wide ecological amplitude being recorded from most vegetated areas. The taxon appears to be a successful stress tolerator. Exceptions include areas of very high animal disturbance and lush vegetated areas inundated with surface water flow. Extensive turfs of Dicranoweisia spp. can be found, similar to those of Ditrichum immersum. In bryophytedominated areas, cover dominance or co-dominance of this taxon suggests that Dicranoweisia spp. are competitively successful. However, the relative cover of the taxon is reduced in areas of extensive stands of Azorella selago.

Notes: Dicranoweisia spp. occur on Marion and Prince Edward Islands in environments similar to those on Heard Island, but they do not appear to play such a dominant role.

FIG. 1 (left) - Dendrogram showing TWINSPAN taxon classification of bryophytes and vascular plants, based on presencelabsence data. 


\section{Ditrichum immersum}

Life form: Moss cushion and turf

Ecological amplitude: The species occurs as cushions and turfs in mesic and exposed sites where wind driven mist is the predominant moisture source. The species is generally in areas with stable substrates distant from the coast. At some sites, $D$. immersum cushions and turfs coalesce to form extensive bryophyte stands (pl. 1B) with other taxa such as Dicranoweisia spp.

Notes: Ditrichum immersum is particularly abundant in the northern and southern ice-free areas on Heard Island. Hebrard (1970) reported the genus Ditrichum as occurring preferentially on acidic environments on Îles Crozet and Îles Kerguelen. However, on Heard Island, D. immersum was found growing on limestone-derived moraine on the southern side of the Laurens Peninsula, as well as at other sites. Moist, limestone-derived moraines are likely to be alkaline.

\section{Polytrichastrum alpinum}

\section{Life form: Open carpet moss.}

Ecological amplitude: Polytrichastrum alpinum exhibits wide ecological amplitude on Heard Island. The species usually grows as small, loose, open carpets in gravel or ash/sand or single stems growing between branches of Azorella selago. Notes: This species exhibits similar ecological amplitude on Marion and Prince Edward Islands, Macquarie Island and in alpine N.S.W. The extensive rhizoidal matting of this species, along with the root systems of Colobanthuskerguelensis and Poa kerguelensis, may contribute significantly to the stabilisation of bare ground on Heard Island.

\section{Racomitrium crispulum}

Life form: Moss turf.

Ecologicalamplitude: Racomitrium crispulum is a wide-ranging species on Heard Island, recorded from dry to mesic sites and from coastal to $250 \mathrm{~m}$ a.s.l. Single species turfs were usually found growing in gravel/ash/sand substrates. Often the species was a component of mixed turfs, on a variety of substrates such as thin peaty layers over lava. Although the species is widespread, total cover in any one area was not high.

Notes: On Macquarie Island, $R$ crispulum is a major component of vegetation in feldmark terraces, where extensive turfs of the species occur on terrace risers (Bergstrom \& Selkirk 1999). Comparable turfs were not found on Heard Island: the niche occupied by $R$. crispulum on Macquarie Island appears to be filled by Dicranoweisia spp. on Heard Island.

\section{Sainionia uncinata}

Life form: Range from moss carpets to mats.

Ecological amplitude: Sainionia uncinata was recorded generally in mesic to hydric sites, on both lava and moraine. Lush carpets were recorded in areas of lateral surface drainage. In drier sites the species grows in a tighter mat form.

\section{Vascular plants}

\section{Azorella selago}

Life form: Cushion, with extensive tap root system and contractile roots (Ashton \& Gill 1965).

Ecological amplitude: Azorella selago is by far the most widespread, abundant and dominant plant species on Heard Island. It was recorded in $80 \%$ of all quadrats surveyed in this study and occurred in all of the 15 TWINSPAN
Groups. It occurs throughout the range of environments in which terrestrial plants grow on Heard Island: from coastal beaches up to $400 \mathrm{~m}$ a.s.l., from protected to exposed sites pl. 1C, D). In some areas it can even be found growing in a semi-aquatic environment, such as on the edge of Spit Bay Hut Creek. It is a successful coloniser of moraine slopes and other unstable ground. Shallow substrates appear to restrict the growth of $A$. selago cushions. Other limiting factors appear to be the very steep slopes and extreme environ ments, which occur with increasing al citude and limit all other plant growth on the island. Azorella selago can clearly be described as a "tolerator" and, considering its dominance of vegetated areas on Heard Island at present, a relatively successful competitor in most areas.

Notes: Vegetation dominated by Azorella sp. can be found on all Subantarctic island groups other than South Georgia (Greene \& Walton 1975).

\section{Colobanthus kerguelensis}

Life form: Very small, low-growing, flowering cushion plant. Ecological amplitude: Colobanthus kerguelensis is another species with very wide ecological amplitude. The species generally grows in gravel or ash/sand. It was recorded from most vegetated areas, exceptions being high-altitude, rocky habitats and areas of extensive animal disturbance.

Notes: Scott (1990) reported C. kerguelensis growing in crevices between rocks and in the lee of boulders on welldrained moraines on Heard Island. These micro-habitats are likely to be areas of greater moisture availability or protection from wind exposure.

\section{Poa cookii}

Life form: small tussock grass.

Ecological amplitude: Poa cookii is widespread on Heard Island, occurring from coastal to high altitudes. The species is an effective indicator of nutrient-enriched soil conditions. Extensive stands occur near seal and seabird areas.

Notes: Similar patterns of distribution of this species have been reported on Marion and Prince Edward Islands (Gremmen 1982) and can also be found on Macquarie Island but to a lesser extent, affected by competition from more aggressive tussock grasses.

\section{Poa kerguelensis}

Life form: Small tufted grass, generally less than $20 \mathrm{~cm}$ high. Ecological amplitude: This species is considerably widespread but very rarely forms extensive stands (some swards were recorded at the base of Macey Cone, Laurens Peninsula, with a cover of greater than $50 \%$ ). Generally the species occurs as sporadic tufts. Of the 163 records of P. kerguelensis from quadrats in the vegetation survey, 154 of these had cover values of $5 \%$ or less. The species is prevalent in gravels and sands. It is common in xeric, exposed conditions, although it also grows on stream banks. The species can be found in relatively unstable substrates, such as in areas of frost-heaving, ice-cored moraines and stream banks, and appears to possess characteristics of a ruderal species. It was not recorded in environments with enriched nutrient status or animal disturbance.

Notes: Hughes' (1987) report of P. kerguelensis only from feldmark categories is an under-representation of distribution of the species. It is widely distributed in Hughes' cushion carpet category. Scott (1990) recorded P. kerguelensis in areas similar to those described here, as well as sites recently exposed by glacial recession, post- 1947 . 


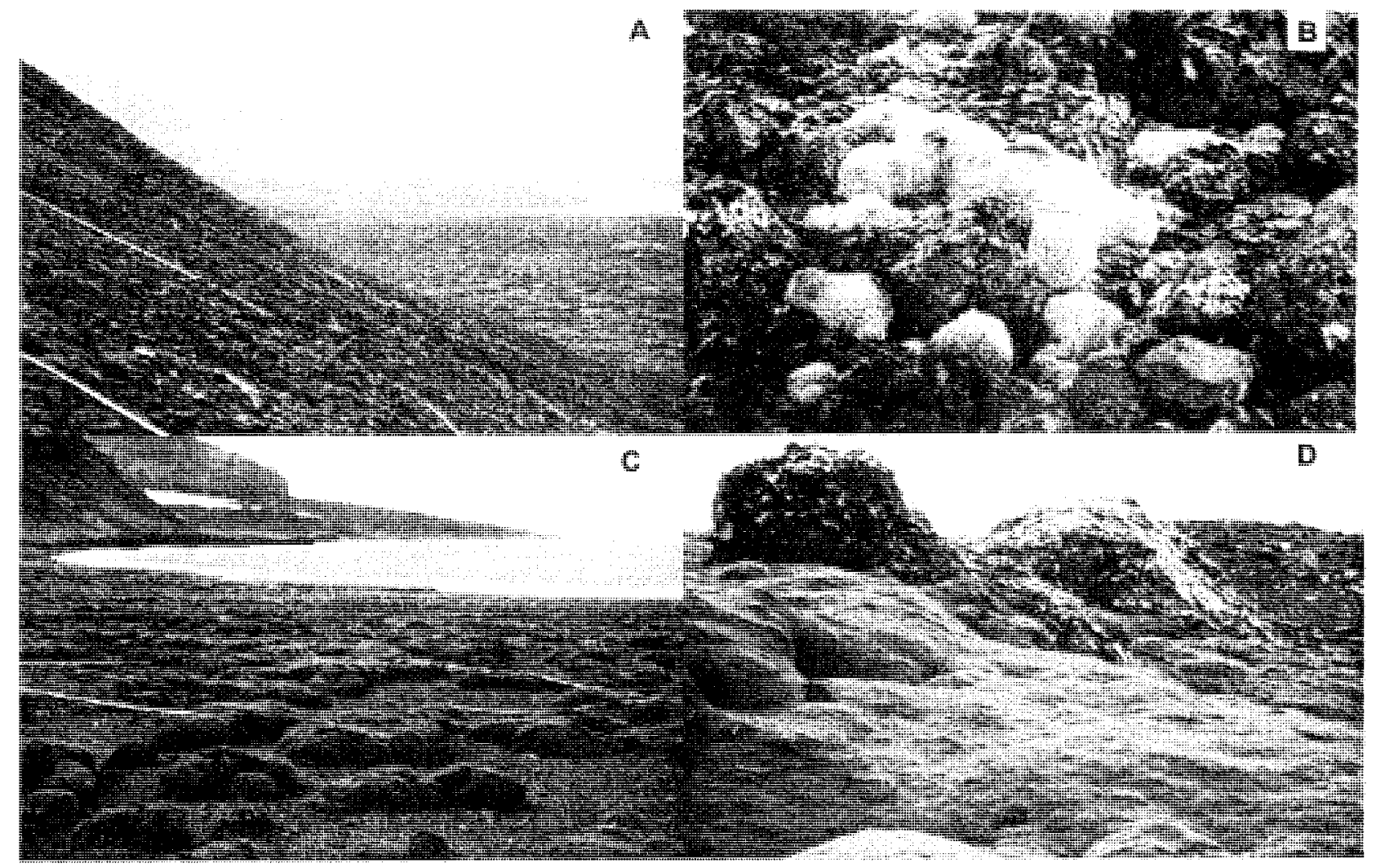

PLATE 1

(A) TWINSPAN Group 4. Slope of Corinth Head (scoria cone), Azorella Peninsula. A mix of bryophyte and Azorella selago vegetation cover. (B) TWINSPAN Group 2. Lush cover of mosses Blindia robusta and Ditrichum immersum, Deacock Moraine, Long Beach. (C) TWINSPAN Group 6. Azorella selago cushions with occasional moss polsters of Dicranoweisia spp. (D) TWINSPAN Group 15. Dense A. selago cushion carpet.

\section{Pringlea antiscorbutica}

Life form: Perennial suffrutescent herb, up to $60 \mathrm{~cm}$ tall. Ecological amplitude. Pringlea antiscorbutica is widespread on Heard Island, occurring from coastal environments to the extreme limits of plant growth at higher altitudes. Hughes (1987) reported P. antiscorbutica at low frequencies in all her vascular plant community categories. She described the species as an "opportunistic species which colonises newly disturbed areas such as landslides and recently deposited moraines". Scott (1988) reported the species growing along edges of gravelly streams, lakes, old river terraces and on scree slopes, and also luxuriant growth of $P$. antiscorbutica adjacent to penguin colonies and monospecific stands on sheltered moraine slopes. Pringlea antiscorbutica can be considered to be an effective ruderal species, occurring preferentially on gravel or ash/sand substrates particularly in morainic debris. Many of the moraine sites are ice-cored and/or unstable.

Notes: Young \& Schofield (1973) suggested that on Îles Kerguelen "Pringlea is tolerant of low temperatures and high winds, but requires a continuous supply of moisture and good drainage". This description is consistent with the distribution of the species on Heard Island. Young \& Schofield also reported (1973) from microfossil studies that Pringlea was present on Îles Kerguelen during the last glacial maximum and suggested that the species is a remnant of a Tertiary Kerguelen flora. As a result of recent studies on Îles Kerguelen, P. antiscorbutica is described as occurring from sea-level to $1000 \mathrm{~m}$ altitude in conditions of salinity, high wind exposure, permanent cold temperatures and frequent freeze-thaw cycles, and as having the widest ecological amplitude of the flowering plants in the region (Hennion 1992, Hennion \& Bouchereau 1998).

\section{NOTES ON OTHER TAXA}

The following species, although not as significant and widespread as those listed above, are characteristic components of some vegetation on Heard Island.

\section{Liverworts}

\section{Blepharidophyllum densifolium}

Generally recorded from stable mesic rocky feldmark sites often with Pedinophyllopsis abdita.

\section{Fossombronia australis}

Very widespread on Heard Island but was never recorded as abundant at any particular site. It was generally seen growing in gravel at the edge of Azorella selago cushions or growing between branches of $A$. selago with rhizoids anchored in a mixture of humic material such as abscised leaves and accumulated wind blown sediment. 


\section{Herzogobryum atrocapillum}

A very tiny, threadlike liverwort. It was recorded mainly from mesic scoria and stable rocky moraines with high bryophyte cover. Single stems were commonly found interwoven with other bryophytes.

\section{Pedinophyllopsis abdita}

A common liverwort in the northern and southern regions of Heard Island. It was recorded from a range of coastal to high altitude mesic environments, but generally not in sites with significant nutrient enrichment. It grows as a mat or as single stems entangled with other plants.

\section{Mosses}

\section{Andreaea mutabilis and Schistidium apocarpum}

Rock-colonising bryophytes that were commonly growing in stable areas on large scoria boulders or rocks in moraine. Many records of these species were at high altitude sites such as on Deacock Moraine, Long Beach region.

\section{Blindia robusta}

Occurs in extensive lush stands on moraine, cliffs and lava on the eastern and southern sides of Heard Island (pl. 1B).

\section{Brachythecium species}

Generally confined to areas of lateral water flow, such as on slopes below springs or in areas of meltwater drainage from ice-cored moraines. Scott (1990) reported Brachythecium spp. growing on wet cliff ledges below waterfalls.

\section{Bryum pseudotriquetrum}

Another widespread but not abundant bryophyte on Heard Island. It was often recorded as single stems amongst Azorella selago cushions, but could also be found in hydric zones such as at the edge of glacial lakes and streams in meltwater areas in generally unvegetated ice-cored moraines. Scott (1988) reported B. pseudotriquetrum with Poblia wablenbergit colonising areas exposed to spray from waterfalls.

\section{Ceratodon purpureus}

Like Fossombronia australis, widespread on Heard Island but never recorded as very plentiful. It was most commonly found growing in gravel and spanned a large range of environments from xeric exposed moraines to flush zones.

\section{Polytrichum piliferum}

Recorded on Heard Island only from moraines. It generally grows in gravel or fines and appears to tolerate xeric conditions and unstable substrates, anchoring to the substrate with rhizoidal mats.

\section{Vascular Plants}

\section{Acaena magellanica}

Recorded from the southeastern ice-free areas on Heard Island, between Fifty-one Glacier and Fairchild Beach (Scott 1988). This species most often grows on moist slopes, generally in association with other species such as Azorella selago and Poa cookii. Scott (1988) also reported it growing with Pringlea antiscorbutica.

\section{Callitriche antarctica and Montia fontana}

Restricted to nutrient enriched, moist environments such as the edges of seal wallows (Hughes 1987, Whinam 1989, Scott 1989). Montia appears to have a restricted distribution on the island (Scott 1988).

\section{Deschampsia antarctica}

Has been noted in the eastern areas on Heard Island growing in drainage lines and springs (Hughes 1987, Scott 1988).

\section{CONCLUSION}

Heard Island has an extremely varied range of terrestrial environments in which distinct suites of species occur. This study has begun to describe the ecological amplitude of these species. There are two striking features of terrestrial plant ecology on Heard Island. The first is the dominance of bryophytes in terms of species richness; the second is the dominance of Azorella selago in terms of abundance and distribution.

Though Azorella occurs on most of the other Subantarctic islands, its distribution on these islands is restricted, generally to higher altitudes or exposed situations. Bergstrom et al. (1997) reviewed data on Azorella spp. in the Subantarctic. Generally Azorella (both $A$. selago and $A$. macquariensis) exhibit slow growth rates, slow floral development and limited successful sexual reproduction; they are outcompeted by more aggressive and/or taller plant species. With the cooler temperatures and limited vascular flora of Heard Island, $A$. selago is not subjected to significant competition from other vascular species.

There is, however, a very high chance that this situation will change with time. Climatic amelioration in association with glacial retreat will create opportunities for new species to colonise, become established and ultimately interact with the species already established on the island.

There has been minimal human impact on the terrestrial ecosystem of Heard Island. Chown et al. (1998), predictably found a relationship between species introduced by humans and the number of human occupants and/or visitors to Subantarctic islands. Bergstrom \& Chown (1999) concluded that functional groups previously not found on Subantarctic islands have a substantial likelihood of becoming invasive and that warmer conditions will increase the ease with which this can happen. Given the low species diversity on Heard Island, the spectrum of potential invasive plants is very large.

This study provides a baseline from which to recognise and document change in the terrestrial ecosystems of the island. The combination of climate change and increased ecotourism interest, makes ecological change on Heard Island inevitable.

\section{ACKNOWLEDGEMENTS}

This work was supported by the Australian Antarctic Program and by Macquarie University. We thank the Australian Antarctic Division for logistic support for fieldwork. We thank two referees for their helpful comments on an earlier version of this article. 


\section{REFERENCES}

ALISON, I.F. \& KEACE, P. L., 1986: Recent changes in the glaciers of Heard Island. Polar Rec. 23: 255--271.

Ashton, D.H. \& Gill, A.M. 1965: Pattern and process in a Macquarie Island feldmark. Proc. R. Soc. Vict. 79: 215245.

Australian Antarctic Division, 1995: Heard Island Wildemess Reserve Management Plan. Department of the Environment, Sport and Territories, Canberra: $72 \mathrm{pp}$.

BERGSTROM, D.M. \& CHOWN, S.L., 1999: Life at the front: history, ecology and change in southern ocean islands. Trends Ecol. Evol. 14: $472-477$.

BERGSTROM, D.M. \& SfLkirk, P.M., 1997: The disrribution of bryophytes on subantartic Hcard lsland. Bryologist 100: 349-355.

Bergisirom, D.M. \& SElkiRK, P.M., 1999: Bryophyte propagule banks in feldmarks on Macquarie Island. Arct., Aniarct. Alp. Res. 31: 202-208.

Bergstrom, D.M. \& Seppelt, R.D., 1988: The moss flora of Heard Island: revised checklist, annotations and phytogeographical considerations. Lindbergia 14: 184190.

Bergstrom, D.M., Selkirk, P.M., Keenan, H. \& Wil.son, M.E., 1997: Reproductive behaviour of ten flowering plant species on subantarctic Macquarie Island. Opera Bot. 132: $109-120$

BRAUN-BlanQUET, J., 1932: PLANT SOCIOLOGY: THESTUDY OF PLANT COMMUNTTIES (trans., rev., ed. Fuller, G.D. \& Conard, S.). Conards, McGraw-Hill, New York.

Chown, S.L., Gremmen, N.J.M. \& Gaston, K.J., 1998: Ecological biogeography of southern ocean islands: species relationships, human impacts and conservation. Am. Nat. 152: 562-575.

Clarke, I., McDougall, I. \& Whitford, D.J., 1983: Volcanic evolution of Heard and McDonald Islands, Southern Indian Ocean. In Oliver, R.L., James, P.R. \& Jago, J.B. (Eds): ANTARCTIC EARTH SCIENCE. Cambridge University Press, Cambridge: 631-635.

Climap Project Members, 1976: The surface of the Ice-age Earth. Science 191: 1131-1137.

Erskine, P.D., Bergstrom, D.M., Schmidt, S., STewart, G.R. Tweedie, C.E. \& Shaw, J.D., 1998: Subantarctic Macquarie Island - a model system for studying animal derived nitrogen sources using ${ }^{15} \mathrm{~N}$ natural abundance. Oecologia 17: 187-193.

Gimingham, C. H. \& Birse, E. M., 1957: Ecological studies on growth form in bryophytes. I. Correlations between growth form and habitat. J. Ecol. 45: 553-545.

Greine, S.W. \& WaLton, D.W.H., 1975: An annotated check list of the subantarctic and Antarctic vascular flora. Polar Rec. 17: 473-484.

GREMMEN, N.J.M., 1982: THE VEGETATION OF THE SUBANTARCTIC ISLANDS MARION AND PRINCE EDWARD. W. Junk Publishers, The Hague: $149 \mathrm{pp}$.

Grime, J.P., 1979: PIANT STRATEGIES AND VEGETATION PROCESSES. Wiley, Chichester: $222 \mathrm{pp}$.

Hebrard, J.P., 1970: Muscinées recoltées aux Illes Kerguelen et Crozet pendant la campagne d'été des 'Terres Australes et Antarcriques Française (1969). Rev. Bryol. Lichenol. 37: $135-162$.

Hennion, F., 1992: Etude des caractéristiques biologiques et génétiques de la flore endémique des îles Kerguelen.
PhD Thesis, Muséum National d'Histoire Naturelle, Paris.

Hennion, F. \& Bolchereal; A., 1998: Accumulation of organic and inorganic solutes in the subantarctic cruciferous species Pringlea antiscorbutica in response to saline and cold stress. Polar Biol. 20: 281-291.

IYll., M.O., 1979: TWTNSPAN - a FORTRAN program for arranging mulizuariute data in an ordered two-way table by classification of the individuals and attributes. Ecology and Systematics Section, Cornell University, Ithaca, New York.

Hughes, J.M.R., 1987: The distribution and composition of vascular plant communities on Heard Island. Polar Biol. 7: $153-162$.

JENKIN, J.F., 1975: Macquarie Island, subantarctic. In Rosswall, T. \& Heal, O.W. (Eds): STRUCTURE AND FUNCTION OF TUNDRA ECOSYSTEMS. Swedish Natural Science Research Council, Stockholm: 375-397.

JENKIN, J.F., 1980; Botany. In Veenstra, C. \& Manning, J. (Eds): Expedition to the Australian Territory of Heard Island and McDonald Islands, 1980. Div. Natl Mapp., Dep. Natl Dev. Energy, Canberra Tech. Rep. 31: 43-45.

LeDingham, R., 1987: Local weather. In Ledingham, R. (Ed.): Heard Island Expedition ANARE 1986-87. Rep. to Aust. Antarct. Div.: 127-130.

Matuls, M., 1988: A quantitative analysis of aerosol (salt) scavenging on Macquarie Island. Pap. Proc. R. Soc. Tasm. 122: $121-128$.

Quilty, P.G., Shafik, S., McMinn, A., Brady, H., \& Clarke, I., 1983: Microfossil evidence for the age and environment of deposition of sediments of Heard and McDonald Islands. In Oliver, R.L., James, P.R. \& Jago, J.B. (Eds): ANTARCTIC EARTH SCIENCE. Cambridge University Press, Cambridge: 636-639.

SCOTT, J.J., 1988: Vegetation Studies. 1987-1988 ANARE Heard Island Report. Unpublished.

Scort, J.J., 1989: New records of vascular plants from Heard Island. Polar Rec. 25: 37-42.

Sco'TT, J.J., 1990: Changes in vegetation on Heard Island 19471987. In Kerry, K.R. \& Hempel, G. (Eds): ANTARCTIC ECOSYSTEMS, ECOLOGICAL CHANGE AND CONSERVATION. Springer Verlag, Berlin: 61-76.

SмITH, V.R., 1987: Chemical composition of precipitation at Marion Island. Atmos. Environ. 21: 1159-1165.

SmITH, V.R. \& FrenCH, D.D., 1988: Patterns of variation in the climates, soils and vegetation of some subantarctic and antarctic islands. S. Afr. J. Bot. 54: 35-46.

Smith, V.R. \& STEENKAmp, M., 1990: Climate change and its ecological implications at a subantarctic island. Oecologica 85: 14-24.

VERwOERD, W.J., 197 1: Geology. In Zinderen Bakker Sr, E.M.v., Winterbottom, J.M. \& Dyer, R.A. (Eds): MARIONAND PRINCE EDWARD ISLANDS. Balkema, Cape Town: $40-62$.

Whinam, J., 1989: Structure and floristic composition of the Heard Island "pool complex" community. Polar Biol. 9: 499-503.

Young, S.B. \& Schorreld, E.K., 1973: Palynological evidence for the late glacial occurrence of Pringlea and Lyallia on Kerguelen 1stand. Rhodora 75: 239-247.

(accepted 5 July 1999) 
APPENDIX

TWINSPAN group details

TWINSPAN Group $\mathbf{1}, \mathrm{n}=17$ quadrats

Mean altitude. high $>200 \mathrm{~m}$ a.s.l.

Moisture: mesic

Wind exposure: medium

Mean substrate depth: $5 \mathrm{~cm}$

Mean rock cover: $37 \%$

Mean bare ground cover: $10 \%$

Mean total bryophyte cover: $47 \%$

Mean Azorella selago cover: $1 \%$

Geomorphology: exclusively moraine, "boulder scree"

TWINSPAN indicator species: Andreaea mutabilis \&

Schistidium apocarpum

Community categories: overwhelming feldmark

Notes: Group 1 consists of quadrats from one local area, Deacock Moraine, Long Beach. The group is characterised by a predominance of bryophytes, both in species richness (26 taxa) and cover. In some quadrats, bryophyte cover exceeded $80 \%$. The ground was stable, rocky moraine with minimal skeletal soil development. This is highlighted by the two indicator species, the mosses Andreaea mutabilis and Schistidium apocarpum being rock colonisers. Lichens,

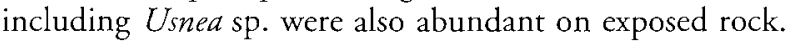
Areas with a developed peaty layer $(2-5 \mathrm{~cm})$ had developed lush turves and carpets dominated by either/and Dicranoweisia spp., Blindia robusta and Sainionia uncinata. Only two vascular species, Poa kerguelensis and Azorella selago were recorded, both with sparse cover.

TWINSPAN Group 2, $\mathrm{n}=54$

Mean altitude: medium, $50 \mathrm{~m}$ a.s.l.

Moisture: mesic

Wind exposure: medium

Mean substrate depth: $15 \mathrm{~cm}$

Mean rock cover: $11 \%$

Mean bare ground cover: $18 \%$

Mean total bryophyte cover: $35 \%$

Mean Azorella selago cover: $16 \%$

Geomorphology: lava and stable moraines

TWINSPAN indicatorspecies: Blepharidophyllum densifolium and Verrucidens spp.

Community categories: predominantly feldmark

Notes: Group 2 consists of quadrats in which bryophytes are overwhelmingly the dominant component, both in terms of cover and diversity (40 taxa in total). Thirty-three quadrats had lush bryophyte carpets, exceeding $50 \%$. Stability of habitat appeared to be an important factor and shallow substrate depth reduced competition from Azorella selago. Major bryophyte species included Blindia robusta, Ditrichum immersum, Dicranoweisia spp. and Bartramia patens as well as the indicator taxa. This group included sites in the $\mathrm{Mt}$ Drygalski area, Long Beach (pl. 1B) and lavas on the Laurens Peninsula, as well as sites on limestone at the southern base of Anzac Peak.

TWINSPAN Group 3, $\mathrm{n}=40$ quadrats

Mean altitude: medium, $50 \mathrm{~m}$ a.s.l.

Moisture: mesic

Wind exposure: medium

Mean substrate depth: $18 \mathrm{~cm}$

Mean rock cover: $13 \%$

Mean bare ground cover: $20 \%$
Mean total bryophyte cover: $27 \%$

Mean Azorella selago cover: $23 \%$

Geomorphology:varied, lava--scoria and flows, moraines and sand

TWINSPAN indicator species: Sainiona uncinata

Community categories: dense cushion carpet, patchy cushion carpet and feldmark.

Notes: As with Group 2, bryophyte diversity is very high (total 42 taxa), with the main distinguishing feature between this group and Group 2 being prominence of Azorella selago. Carpets of Sainionia uncinata were also recorded. The presence of this species is a good indication of mesic conditions. Dicranoweisia spp. and Ditrichum immersum were also abundant bryophyte taxa, with Blindia robustaless conspicuous. Ten quadrats in Group 3 had Poa cookii present, perhaps reflecting slightly higher nutrient status. Sites were recorded from stable lava or moraine, or sand such as on strearns banks. Group 3 included sites from all major vegetated regions as well as Capes Pillar, Arkona and Gazert.

TWINSPAN Group 4, $\mathrm{n}=51$ quadrats

Mean altitude: high, $90 \mathrm{~m}$ a.s.l.

Moisture: mesic

Wind exposure: medium to exposed

Mean substrate depth: $11 \mathrm{~cm}$

Mean rock cover: $15 \%$

Mean bare ground cover: $22 \%$

Mean total bryophyte cover: $33 \%$

Mean Azorella selago cover: $11 \%$

Geomorphology: predominantly lava scoria and flows

TWINSPAN indicator species: Dicranoweisia spp. and Bartramia patens

Community categories: patchy cushion carpet and feldmark Notes: Group 4 contains quadrats similar in species composition to Groups 2 and 3. Bryophyte species richness is fairly high (total 34 taxa). However, sites are mainly on lava and are more exposed and drier than those in the previous two groups. Azorella selago cover is low. Sites include areas at the base of Macey Cone and on the slopes of Corinth Head (pl. 1A). Lava ridges southwest of Cape Cartwright and the higher vegetated slopes of Deacock Moraine.

TWINSPAN Group 5, $\mathrm{n}=15$ quadrats

Mean altitude: high $90 \mathrm{~m}$ a.s.l.

Moisture: predominantly xeric

Wind exposure: exposed

Mean substrate depth: $10 \mathrm{~cm}$

Mean rock cover: $25 \%$

Mean bare ground cover: $23 \%$

Mean total bryophyte cover: $45 \%$

Mean Azorella selago cover: $5 \%$

Geomorphology: predominantly scoria

TWINSPAN indicator species: Herzogobryum atrocapillum and Lophocolea sp. 1.

Community categories: feldmark

Notes: Group 5, with very exposed scoria slopes, represents the extreme end of a continuum from Groups 2-4. Although very exposed the sites were mesic from deposition of winddriven moisture. Bryophyte species richness was low, although total bryophyte cover was high, suggesting reduced habitat 
variety. Azorella selago cover was low, again reflecting shallow substrate depth. Most sites were on high slopes of Macey Cone.

TWINSPAN Group 6, $\mathrm{n}=67$

Mean altitude medium $40 \mathrm{~m}$ a.s.l.

Moisture: predominantly xeric

Wind exposure: exposed

Mean substrate depth: $18 \mathrm{~cm}$

Mean rock cover: $18 \%$

Mean bare ground cover: $39 \%$

Mean total bryophyte cover: $11 \%$

Mean Azorella selago cover: $20 \%$

Geomorphology: exclusively moraine

TWINSPAN indicator species: Fossombronia australis

Community categories: generally patchy cushion carpet

Notes: Most sites in Group 6 were from the Dovers Moraine area, Spit Bay and Long Beach area (pl. 1C). The sites were generally characterised by small Azorella selago cushions with occasional clusters of small moss polsters, surrounded by windswept gravel. In some sites there was evidence of frost raking and nubbin formation running parallel with the prevailing wind direction. The indicator species, Fossombronia australis, most often was found having colonised the edges of or spaces between branches of $A$. selagocushions. Azorella selago, Poa kerguelensis, Colobanthus kerguelensis, Dicranoweisia spp. and Polytrichastrum alpinum were recorded from most of the 67 quadrats in this group.

TWINSPAN Group 7, $\mathrm{n}=18$

Mean altitude medium, $60 \mathrm{~m}$ a.s.l.

Moisture: predominantly xeric

Wind exposure: exposed

Mean substrate depth: $10 \mathrm{~cm}$

Mean rock cover: $38 \%$

Mean bare ground cover: $37 \%$

Mean total bryophyte cover: $7 \%$

Mean Azorella selago cover: $8 \%$

Geomorphology: exclusively moraine

TWINSPAN indicator species: Ceratodon purpureus and Polytrichum piliferum

Community categories: feldmark

Notes: This group represents an extension from Group 6, with most sites on Dovers Moraine. Most sites were extremely exposed and xeric. Many sites had evidence of periglacial activity such as nubbin, frost-raking and sorted pavement. There was little vegetation, either bryophytes or vascular plants. Species diversity was low. The indicator species, Ceratodon purpureus and Polytrichum piliferum, were often found growing in gravel and fines and appeared to tolerate surface movement.

TWINSPAN Group 8, $\mathrm{n}=30$

Mean altitude. medium, $50 \mathrm{~m}$ a.s.l.

Moisture: xeric to medium

Wind exposure: exposed to protected

Mean substrate depth: $18 \mathrm{~cm}$

Mean rock cover: $40 \%$

Mean bare ground cover: $11 \%$

Mean total bryophyte cover: $15 \%$

Mean Azorella selago cover: $14 \%$

Geomorphology: exclusively moraine

TWINSPAN indicator species: Poa kerguelensis and

Colobanthus kerguelensis
Community categories: patchy cushion carpet

Notes: Group 8 is another variation on Group 6, occurring in drainage lines and beside streams. The sites were wetter than those of the previous groups, and this is reflected in a high number of Bryaceae taxa occuring in some quadrats (see table 2). The sites were exclusively in the Dovers Moraine area, Spit Bay.

TWINSPAN Group 9, $\mathrm{n}=30$ quadrats Mean altitude medium low, $35 \mathrm{~m}$ a.s.l.

Moisture: xeric to hydric

Wind exposure: exposed to medium

Mean substrate depth: $47 \mathrm{~cm}$

Mean rock cover: $5 \%$

Mean bare ground cover: $14 \%$

Mean total bryophyte cover: $19 \%$

Mean Azorella selago cover: $43 \%$

Geomorphology: predominantly moraine

TWINSPAN indicator species: Polytrichastrum alpinum

Community categories: mixed

Notes: Group 9 consists of quadrats which would span all of Hughes' (1987) community categories except maritime grassland. The cornmon feature of the sites was that they were generally on moraine, and common taxa included Azorella selago (with high cover values) and the indicator species, Polytrichastrum alpinum. Unconsolidated substrate depth was high with a mean of $47 \mathrm{~cm}$, this being an underestimate as many sites had depth greater than the limit of measurement $(100 \mathrm{~cm})$. Most sites were in the Dovers Moraine area.

TWINSPAN Group 10, $\mathrm{n}=16$ quadrats

Mean altitude. low, $30 \mathrm{~m}$ a.s.l.

Moisture: hydric

Wind exposure: medium to protected

Mean substrate depth: $56 \mathrm{~cm}$

Mean rock cover: $0 \%$

Mean bare ground cover: $12 \%$

Mean total bryophyte cover: $11 \%$

Mean Azorella selago cover: $32 \%$

Geomorphology: predominantly moraine

TWINSPAN indicator species: Montia fontana

Community categories: Predominantly pool complex and patchy cushion carpet

Notes: This group contains quadrats on or near impeded drainage areas on moraine substrates close to the coast. This is reflected by the indicator species being Montia fontana. The sites generally have large coalescing cushions of $A$ zorella selago with deep, unconsolidated substrates or peat depths exceeding $100 \mathrm{~cm}$ at many sites. Many cushions flank pools. Nutrient status of the sites was high, with the nitrophiles Poa cookii and Callitriche antarctica in the majority of the quadrats. The source of nutrient enrichment was the wallows of elephant seals. Bryophytes consisted mainly of small cushions of Dicranoweisia spp. at the edge of $A$. selago cushions, Polytrichastrum alpinum growing in gravel, Fossombronia australis growing beside or in A. selago cushions and Brachythecium spp. growing in moist or wet areas at the edge of pools. The sites had wide distribution including areas in Dovers Moraine, Long Beach and Atlas Cove. 
TWINSPAN Group 11, $\mathrm{n}=23$ quadrats

Mearaltitude. medium to low, $20 \mathrm{~m}$ a.s.l.

Moisture: hydric

Windexposure: medium to protected

Meansubstrate depth: $50 \mathrm{~cm}$

Mean rock cover: $0 \%$

Mean bare ground cover: $3 \%$

Mean total bryophyte cover: $56 \%$

Mean Azorella selago cover: $16 \%$

Geomorphology: exclusively moraine

TWINSPAN indicator species: Marchantia berteroana

Community categories: mixed; however, meadow and herbfield more common

Notes: Group 11 consisted mainly of wet sites which could be classified as meadow and herbfield. Vegetation cover was high and total bryophyte cover was very extensive. Majot vascular species included mats of Acaena magellanica and tufts of Deschampsia antarctica and Poa cookii. Azorella selago occurred in all quadrats of this group, although it was not a dominant species in terms of cover. Major bryophyte species included mats of Marchantia berteroana, lush carpets of Sainionia uncinatus and turves of Bryum pseudotriquetrum. Many sites had peat depths exceeding $100 \mathrm{~cm}$. Sites were recorded from Sydney Cove, Long Beach and Dovers Moraine.

TWINSPAN Group 12, $\mathrm{n}=13$ quadrats

Mean altitude. low, $15 \mathrm{~m}$ a.s.l.

Moisture: mesic

Wind exposure: medium

Mean substrate depth: $30 \mathrm{~cm}$

Mean rock cover: $7 \%$

Mean bare ground cover: $1 \%$

Mean total bryophyte cover: $50 \%$

Mean Azorella selago cover: $7 \%$

Geomorphology: exclusively moraine

TWINSPAN indicator species: Brachythecium spp.

Community categories: Predominantly meadow

Notes: Group 12 consisted mainly of quadrats containing Deschampsia antarctica. Azorella selago abundance was very low and in comparison with Group 11, sites were drier and mean substrate depth considerably shallower. The indicator taxa, Brachythecium spp., often occurred as thick carpets.

TWINSPAN Group 13, $\mathrm{n}=31$ quadrats

Mean altitude. low, $15 \mathrm{~m}$ a.s.l.

Moisture: xeric to mesic

Wind exposure: medium

Mean substrate depth: $28 \mathrm{~cm}$

Mean rock cover: $12 \%$

Mean bare ground cover: $23 \%$

Mean total bryophyte cover: $7 \%$

Mean Azorella selago cover: $20 \%$

Geomorphology: predominantly moraine

TWINSPAN indicator species: Colobanthus kerguelensis

Community categories: mixed but predominantly coastal

Notes: Quadrats in Group 13 were generally from salt- affected coastal sites, including areas that could be classified as maritime grassland, pool complex and low-lying, patchy cushion carpet. Sites were at Sydney Cove, Spit Bay and Atlas Cove, including the supralittoral zone at Atlas Cove. Colobanthus kerguelensis as an indicator species most likely reflects small-scale xeric conditions. Bryophyte richness was low; however, one notable feacure was the presence of Muelleriella crassifolia ssp. acuta in all the supralittoral quadrats. A high occurrence of Poa cookiithroughout reflected a high nutrient status, perhaps blown in from nearby animal disturbed sites.

TWINSPAN Group 14, $\mathrm{n}=21$ quadrats

Mean altitude. low, $13 \mathrm{~m}$ a.s.l.

Moisture: mesic

Wind exposure: exposed

Mean substrate depth: $41 \mathrm{~cm}$

Mean rock cover: $1 \%$

Mean bare ground cover: $27 \%$

Mean total bryophyte cover: $0 \%$

Mean Azorella selago cover: $21 \%$

Geomorphology: predominantly moraine

TWINSPAN indicator species: Poa cookii

Community categories: predominantly maritime grassland

Notes: Group 14 consists of coastal sites near penguin colonies and seal-wallowing areas at Spit Bay and sealwallowing areas at Atlas Cove, and an area approximately $500 \mathrm{~m}$ inland from Long Beach. Poa cookii was the dominant species. No bryophyte taxa were recorded in these quadrats, most likely reflecting animal disturbance and toxic nutrient levels.

TWINSPAN Group 15, $\mathrm{n}=22$ quadrats

Mean altitude. medium, $33 \mathrm{~m}$ a.s.l.

Moisture: mesic

Wind exposure: exposed

Mean substrate depth: $65 \mathrm{~cm}$

Mean rock cover: $0 \%$

Mean bare ground cover: $6 \%$

Mean total bryophyte cover: $0 \%$

Mean Azorella selago cover: $68 \%$

Geomorphology: moraine or sand

TWINSPAN indicator species: Pringlea antiscorbutica

Community categories: predominantly cushion carpet

Notes: Group 15 sites had a very high Azorella selago cover and the occasional occurrence of Pringlea antiscorbutica, Poa cookizand Aceana magellanica (pl. 1D). Pringlea antiscorbutica as an indicator species is not considered to be conclusive. As data was reduced to a presence/absence basis, the extensive cover of Azorella selago in quadrats in Group 15 was not highlighted in the TWINSPAN analysis, as $A$. selagooccurred in $80 \%$ of all the quadrat survey in the study. Group 15 sites were recorded from areas of Dovers Moraine, Long Beach, Atlas Cove and the southern side of the Laurens Peninsula. Unconsolidated substrate depth in these areas often exceeded $100 \mathrm{~cm}$. 